\title{
Ekološka poljoprivreda - indikator društvenih vrednota
}

\author{
Jelena Puđak
}

Institut društvenih znanosti "Ivo Pilar"

jelena.pudjak@pilar.hr

Nataša Bokan

Agronomski fakultet Sveučilišta u Zagrebu

nbokan@agr.hr

\begin{abstract}
SAŽETAK U svjetlu sve obimnijih lokalnih i globalnih ekoloških problema, potrebno je identificirati društvene momente koji čine i/ili izrastaju iz tih problema. Jedan od tih momenata jest proizvodnja hrane kojom se kroz konvencionalnu poljoprivredu doprinijelo okolišnim i društvenim problemima. Ekološka poljoprivreda je alternativni pristup proizvodnji hrane koji implicira određene društvene odnose te odnose prema prirodi i tehnologiji. Iako konvencionalni način uzgoja hrane u svijetu i dalje prevladava, ekološka poljoprivreda se ubrzano širi, kao praksa zdravijeg življenja, kao strategija preživljavanja ruralnog (a ponegdje i urbanog) stanovništva i kao svjetonazor. Iz kojih to činjenica, u kojim oblicima i s kojim implikacijama izrasta ekološka poljoprivreda - pitanja su na koja pokušavamo barem započeti odgovarati u ovom radu. Također, navest ćemo ekološke, ekonomske i sociokulturne dobrobiti ekološke poljoprivrede koje bi danas, zbog neizmjerne i dubinske devastacije okoliša, trebale biti aktualnije nego ikad. Razmotrit ćemo na koji način je ekološka poljoprivreda dio šireg, alternativnog društvenog pokreta i stila življenja. Na kraju donosimo pregled stanja i mogućnosti ekološke poljoprivredne proizvodnje u svijetu i u Hrvatskoj. Zaključit ćemo rad s dvije konstatacije. Zbog paradigmatske odanosti profitno orijentiranom konzumerističkom društvu, prihvaćanje ikakve alternativne ideje i/ili prakse je sporo i u pravilu neprihvatljivo. No, ekološka proizvodnja hrane je ipak ekonomska i društvena djelatnost i društvena vrednota koja doživljava ekspanziju, stoga ju je važno, teorijski i društveno prepoznati te pozicionirati.
\end{abstract}

Ključne riječi: ekološka poljoprivreda, održivost, poljoprivredna proizvodnja, konvencionalni uzgoj, alternativni društveni pokreti.

\section{Uvod}

Unatoč dugoj tradiciji ruralne sociologije u Hrvatskoj, tema proizvodnje hrane kao društveno, sociokulturno i ekološko pitanje mahom je zanemareno. Kloppenburg 
(1991.) tvrdi da bi ruralni sociolozi trebali biti aktivni agenti u konstrukciji alternativne "poljoprivredne tehnoznanosti" što je po njegovom mišljenju ključni preduvjet za razvoj alternativne poljoprivrede. No, (ruralni/e) sociolozi/ginje u Hrvatskoj ne istražuju proizvodnju i konzumaciju hrane, a ni alternativni način razmišljanja o hrani i njezinoj proizvodnji, čime propuštaju kritički komentirati i valorizirati trenutno stanje toga aspekta poljoprivredne proizvodnje i hrane uopće. Društvene promjene koje se događaju na tom području tako ostaju nezabilježene i znanstveno marginal(izira)ne, stoga ćemo posvetiti pažnju nekim aspektima ekološke poljoprivrede kako bi doprinijele sociologizaciji ove teme.

O ekološkoj poljoprivredi potrebno je i korisno govoriti u okviru održivosti, koja se bez obzira na dileme i prijepore oko opsega i dosega samog pojma, smatra društveno poželjnim ciljem. Tako je barem u zemljama, zajednicama i među pojedincima/kama koji promišljaju o posljedicama ukupnog društvenog djelovanja i smjera razvoja.

Ekološka poljoprivreda je jedan od konstitutivnih elemenata ideje održivosti. Prvo, ekološka dimenzija ekološke poljoprivrede predstavlja kritičko promišljanje dosadašnjeg, a ponajprije suvremenog poljoprivrednog razvoja koji se zasniva na intenzivnom korištenju (neobnovljivih) resursa i upotrebi kemikalija u proizvodnji hrane. Danas su poznati i dokazani štetni učinci konvencionalne, intenzivne poljoprivrede, a s druge strane višestruke koristi od ekološke ${ }^{1}$.

Naime, čitava industrija kemijskog gnojenja tla je započela od zaključka Justusa von Liebiga, znanstvenika koji je prvi objavio da dušik, fosfor i kalijev karbonat (NPK u današnjoj kemijskoj poljoprivredi) hrane biljke i uvjetuju njihov rast, te koji je nakon deset narednih godina istraživanja zaključio da tajna gnojenja ipak leži u humusu, a ne u tih nekoliko kemijskih elemenata, no već je bilo kasno za korekciju njegovog "znanstvenog" zaključka na temelju kojeg je industrija kemikalija već solidno zarađivala prodajući kemijsko gnojivo (Tompkins i Bird, 1998.).

Ekološku poljoprivredu se također može/mora promatrati kroz prizmu društvenih vrednota. Postmaterijalističke vrednote društva koje više vrednuje zaštitu okoliša od privrednog rasta, koje ne pokušava stvoriti blagostanje pod cijenu rizika i kojem je najvažnije da je zadovoljen ljudski rad, a ne privredne potrebe (Cifrić, 1994.) podupiru ideju ekološke poljoprivrede u čitavom kompleksu njezinih potencija, ekoloških, ekonomskih i sociokulturnih.

U radu ćemo, nakon kratke sociološke interpretacije ekološke poljoprivrede, predstaviti ekološke, ekonomske i sociokulturne dobrobiti i dobiti ekološke poljoprivrede. Zatim ćemo opisati na koji način je ekološka poljoprivreda dio šireg, alter-

1 Šimleša (2010.) u svojoj knjizi "Ekološki otisak: kako je razvoj zgazio održivost” navodi niz istraživanja koja pobijaju mitove o neproduktivnosti ekološke poljoprivrede i pokazuju mnogostruke prednosti po zdravlje čovjeka, okoliša, a posredno i ekonomije. 
nativnog društvenog pokreta, i stila življenja. Na kraju donosimo pregled stanja i mogućnosti ekološke poljoprivredne proizvodnje u svijetu i u Hrvatskoj.

\section{Što je ekološka poljoprivreda? - Sociološka interpretacija}

Ekološka poljoprivreda, koja je izvan granica Hrvatske poznatija pod nazivom "organska" (engl. organic agriculture), je najjednostavnije rečeno poljoprivredna metoda koja proizvodi hranu iz zdrave i cjelovite zajednice zemlje i biljaka bez upotrebe mineralnih gnojiva, GM organizama, pesticida i drugih sintetičkih kemijskih preparata. Ekološka poljoprivreda dugoročno poboljšava kvalitetu tla i doprinosi povećanju biološke raznolikosti.

Međutim, smatramo kako ekološka poljoprivreda nije samo poljoprivreda (proizvodnja hrane), koja je ekološka. Pored uže definiranih poljoprivrednih tehnika i metoda, u ekološkoj poljoprivredi se ogleda postmoderni svjetonazor, stil života, te dio šireg društvenog pokreta kojim se ukazuje na potrebu i mogućnost korjenitih promjena u svim sferama društva, u cilju povećanja kvalitete života za sve ljude.

Ekološka poljoprivreda je stoga i jedna od temeljnih egzistencijalnih ljudskih djelatnosti u kojoj se ogleda integralna održivost, pa taj oblik poljoprivrede spada pod krošnju "održive poljoprivrede". "Nije riječ o tehničkim aspektima nego o antropološkom odnosu čovjeka prema Zemlji” (Cifrić, 2003.:9).

No, krenimo redom. Nakon Drugog svjetskog rata zamah uzima danas prevladavajuća, konvencionalna poljoprivreda. Kompanije koje su proizvodile sintetičke kemikalije za vojne potrebe, pred gubitkom tržišta okreću se novim potrošačima - poljoprivrednicima (Motik i Šimleša, 2007.). Farmaceutske kompanije tada počinju nuditi cijeli spektar toksičnih kemikalija u obliku pesticida ${ }^{2}$, hormona rasta, mineralnih gnojiva i dr., čija primjena u kombinaciji sa teškom mehanizacijom i intenzivnim navodnjavanjem, daje vrlo visoke prinose. Tako je započelo doba u razvoju poljoprivrede koje je kasnije nazvano "zelena revolucija". Tehnologija i kemijski poljoprivredni preparati su izvezeni u nerazvijene zemlje s ciljem (ili izlikom) zaustavljana gladi. Pored navedenog, siromašnima je ponuđeno i genetski modificirano sjeme žitarica koje daje obilat urod, dok je istovremeno otporno na pesticide.

Nije trebalo proći dugo vremena da bi se uočile nuspojave ovog instant lijeka za glad, siromaštvo i posrnulu industriju. Ponovo, negativni efekti intenzivne poljoprivredne proizvodnje koja se proširila globalno, nisu bili vidljivi samo na oranicama.

Iako korijene ekološke poljoprivrede možemo tražiti i ranije u prošlosti ${ }^{3}$, jedan događaj (točnije knjiga), bio je zaslužan za podizanje svijesti, i povećanje brige za hranu

2 U koje potpadaju insekticidi, herbicidi, fungicidi i drugi.

3 Pokret ekološke poljoprivrede započinje '30-ih i '40-ih godina 20. stoljeća kao reakcija na sve veće oslanjanje poljoprivredne proizvodnje na sintetička gnojiva. Mineralna gnojiva 
koju jedemo, i način na koji je proizvodimo. Radi se o publikaciji knjige Tiho proljeće američke znanstvenice Rachel Carson 1962. godine. Autorica u knjizi potanko izlaže i dokazuje negativan utjecaj pesticida na okoliš (s naglaskom na ptice), te iznosi oštru

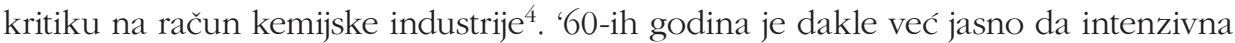
poljoprivreda sa svime što uz sebe veže, ima snažan negativan utjecaj na prirodu, te posljedično i na ljude. Današnja konvencionalna poljoprivreda uzrokuje: eroziju (odn. opustinjavanje) tla, zagađenje tla i podzemnih voda, gubitak humusa i smanjenje plodnosti tla, smanjenje biološke aktivnosti u tlu, te rastuću ovisnost o korištenjem istih kemijskih preparata koji su do problema doveli. Pored toga, konvencionalna poljoprivreda sa svim popratnim sadržajima velik je izvor emisija stakleničkih plinova $^{5}$, te je ovisna o fosilnim gorivima (za tešku mehanizaciju te proizvodnju pesticida i mineralnih gnojiva), što je sve zajedno čini neodrživom. Dakle, posljedicama smanjivanja mogućnosti tla da kontinuirano proizvodi hranu, narušavanja stabilnosti ekosustava, doprinošenju klimatskim promjenama, teškim zdravstvenim (a često i smrtonosnim!) posljedicama za ljude, nije kraj ${ }^{6}$. Danas je jasno kako konvencionalna, odnosno intenzivna poljoprivreda ima sociokulturne i ekonomske implikacije, posebice vidljive u većini zemalja svijeta ${ }^{7}$ (majority world).

Tranzicija s tradicionalne poljoprivrede, u kojoj je proizvodni ciklus u potpunosti zatvoren, na intenzivnu poljoprivredu, koja zahtjeva stalni unos sirovina "izvana", dovodi do široko rasprostranjene pojave kreditnih zaduživanja na selu. Mali seljaci/ poljoprivrednici tako često ulaze u dugove koje kasnije ne mogu vratiti, što dovodi do gubitka zemlje. S druge strane, mnogi mali seljaci/poljoprivrednici ekonomski

stvorena su tokom 18. stoljeća, bazirala su se na superfosfatima i amonijaku, te su se masovno proizvodila Haber-Bosch metodom razvojenom tijekom Prvog svjetskog rata. Ova rana gnojiva su bila jeftina, snažna i jednostavna za transport. Sličan napredak desio se u "40-ima u razvoju kemijskih pesticida, pa se čak cijelo desetljeće naziva "era pesticida".

${ }^{4}$ Iako je nakon objavljivanja knjige autorica bila metom mnogih kritika, čak i prijetnji od strane farmaceutskih, kemijskih i agrotehničkih korporacija, utjecaj knjige bio je globalan, i doveo je do nekih konkretnih zakonskih mjera na području SAD-a. Tadašnji američki predsjednik John F. Kennedy naredio je savjetodavnom Odboru za znanost da istraži Carsoničine tvrdnje. Istraga je potvrdila rezultate do kojih je autorica došla u svojim istraživanjima, što je rezultiralo trenutačnim stupanjem na snagu zakona o regulaciji kemijskih pesticida.

5 Moderna/konvencionalna poljoprivreda u velikoj mjeri doprinosi emisiji stakleničkih plinova - odgovorna je za 14\% ukupnih godišnjih emisija, a uključujući deforestaciju zbog širenja poljoprivrednog zemljišta odgovorna je za narednih 19\%.Od izravnih poljoprivrednih emisija stakleničkih plinova, mineralna gnojiva doprinose s 38\%, a stočarstvo s 31\% (De Schutter, 2010.).

6 Spomenimo samo par primjera: samo svkaka tona mineralnih gnojiva proizvede čak 5 tona $\mathrm{CO}_{2}$, WHO procjenjuje kako je barem 3 milijuna ljudi godišnje otrovano pesticidima, od čega više od 200000 umre, uglavnom u siromašnim zemljama. (Motik i Šimleša, 2007.)

7 Upotrijebile smo termin majority world (ponekad se piše velikim početnim slovima) zbog zastarjelosti i negativne konotacije dosadašnjih termina - zemlje u razvoju (developing countries) i zemlje Trećeg svijeta (Third World countries). Termin nosi ideju da kada se govori o siromašnijim ili deprivilegiranijim zemljama treba imati na umu da one zaiste čine većinu svjetske populacije. 
stradavaju radi padanja cijena što je rezultat ukupne povećane proizvodnje. Istovremeno povećani stupanj mehanizacije koja dolazi ruku pod ruku sa intenzivnom poljoprivredom na većim farmama smanjuje mogućnosti rada i zaposlenja u ruralnoj ekonomiji. Bogatiji seljaci/poljoprivrednici također imaju bolji pristup zemlji i kreditima, te na taj način intenzivna poljoprivreda povećava jaz između bogatih i siromašnih, odnosno povećava klasne nejednakosti. Ovakve novostvorene ekonomske teškoće dovele su do povećane migracije seljaka/poljoprivrednika bezzemljaša sa sela u grad. Jednako tako neke su regije bile spremnije za adaptaciju na intenzivnu poljoprivredu (radi političkih i/ili geografskih razloga), pa dolazi i do povećanja međuregionalnih razlika.

Poznata znanstvenica i aktivistica Vandana Shiva posvetila je život raskrinkavanju svih negativnih implikacija koje je Zelena revolucija imala na okoliš i društvo u Indiji. Multinacionalne korporacije koje su istovremeno vodeće farmaceutske industrije i industrije za proizvodnju sjemena, Shiva dovodi u vezu sa destrukcijom okoliša, biološkom i kulturnom entropijom, te kršenjem ljudskih prava u siromašnim zemljama ${ }^{8}$.

Monokulturni uzgoj, kemizacija poljoprivrede, GM usjevi i biopiratstvo imaju posljedice u socioekonomskoj sferi - osiromašenje ruralnog stanovništva i njihova ovisnost o resursima proizvedenim u kemijskoj ili biotehnološkoj industriji, no također imaju posljedice i u sociokulturnoj sferi - zanemarivanje i zaboravljanje tradicionalnih znanja, gubitak starih sorti, gubitak kulturnih obrazaca tradicijske kulture zbog nadavanja profita kao jedinog principa djelovanja (ekonomskog, pa i društvenog), gubitak zajedništva i solidarnosti u lokalnim zajednicama, devitalizacija ruralnog stanovništva i opća deruralizacija prostora čime se gubi i zaboravlja autohtonost i kulturna baština, jezik, a ono što nastaje je često monokultura - ne samo usjeva, već i kulture. Ukratko, krajnja i sveobuhvatna posljedica jest gubitak identiteta.

Ekološka poljoprivreda ima metode, načela i ciljeve holističke po karakteru, kojima obuhvaća od mjera i metoda obrade zemlje i uzgoja bilja i životinja, do socijalnog i intelektualnog položaja seljaka u društvu. To je sustav gospodarenja koji teži etički prihvatljivoj, ekološki čistoj, socijalno pravednoj i gospodarski isplativoj poljoprivrednoj proizvodnji. Slažemo se sa Cifrićem kada tvrdi da “...ekološka poljoprivreda nije samo poljoprivredna proizvodnja, nego pretpostavlja sasvim određen socijalni sustav - društvo, koji u sebi ima ne samo razvijenu racionalnu

8 U većini svojih knjiga i članaka, Shiva posebnu pažnju posvećuje biopiratstvu. Biopiratstvo predstavlja korporativnu krađu autohtonih (biljnih) sirovina i tradicionalnog znanja o korištenju tih sirovina koja je omogućena i legalizirana putem skupa zakona o intelektualnom vlasništvu nad živim oblicima (TRIPs), a koje su zemlje primorane implementirati i poštovati kroz članstvo u Svjetskoj trgovinskoj organizaciji. Rezultat je stavljnje patenata na cijeli niz autohtonih biljaka i biljnih svojstva koji su se stoljećima koristili u tradicionalnoj poljoprivredi i medicini, nakon čega je siromašnim seljacima u također siromašnim zemljama onemogućeno njihovo korištenje i slobodna razmjena sjemena radi kršenja autorskih prava. Najpoznatiji primjeri biopiratstva su indijsko drvo Neem, i rijetka sorta riže basmati. 
dimenziju primjene najnovijih znanja u poljoprivrednoj proizvodnji i preradi, nego i sustav vrednota (etičkih i estetskih) koji legitimiraju takvu proizvodnju i moralne postupke" (Cifrić, 2003.:13). Tako primjerice krovna organizacija pokreta ekološke poljoprivrede (IFOAM) ${ }^{9}$ kao glavni cilj ekološke poljoprivrede navodi: "Ekološka poljoprivreda je sustav produkcije koji održava zdravlje tla, ekosustava i ljudi. Oslanja se na ekološke procese, biološku raznolikost i cikluse prilagođene lokalnim uvjetima, a ne na korištenje izvanjskih kemikalija sa štetnim posljedicama. Ekološka poljoprivreda kombinira tradiciju, inovaciju i znanost u svrhu dobrobiti za okoliš i kako bi promovirala pravedne odnose i veću kvalitetu života svih koji su uključeni". Ovo nas dovodi do još jedne bitne odrednice ekološke poljoprivrede. Naime, raširena predrasuda o ekološkoj poljoprivredi jest da je ona jednaka tradicionalnoj poljoprivredi, te da je iz istih razloga neekonomična, radno (pre)intenzivna, nepouzdana (radi navodne veće podložnosti vremenskim i drugim utjecajima), te neprihvatljiva modernom (visoko)obrazovanom čovjeku. Ekološka poljoprivreda je koncept poljoprivredne proizvodnje koji je mnogo složeniji i čija bit nije samo u izostavljanju agrokemikalija, već u sveukupnom gospodarenju kojim je to moguće postići. Isto tako, ona nije niti povratak na staro, povratak na poljoprivredu naših djedova i baka. Naprotiv, ekološka poljoprivreda dio je suvremene poljoprivredne proizvodnje, trgovine i agronomske znanosti, te se i temelji na njenim najnovijim spoznajama i dostignućima.

Vratimo se održivosti. Pojavljuju se mnogi pristupi poljoprivrednoj proizvodnji koji za cilj imaju postizanje veće održivosti i od predindustrijskog i od industrijskog poljoprivrednog sustava. Ti pristupi uključuju biodinamiku, lokalnu okolišno osjetljivu poljoprivredu, organsku proizvodnju, permakulturu, i dr. Ideja održive poljoprivrede ne znači potpuno izbacivanje tehnologija i poznatih praksi. Ako neka tehnologija doprinosi poboljšanju produktivnosti, a ne uzrokuje nepopravljive štete za okoliš, onda je vjerojatno da ta tehnologija nosi neke održive dobrobiti. Poljoprivredni sistemi koji uvažavaju ove principe također uključuju i mnoge funkcije unutar lokalne zajednice i ekonomije. Sustav održive poljoprivrede istovremeno proizvodi i hranu i druga dobra za farmere i tržište, ali i doprinosi javnom dobru u obliku čiste vode, biološke raznolikosti, pohranjivanja ugljika u tlo, prevencije poplava, obnovljivosti podzemnih voda, te turizma.

Kako održiva poljoprivreda želi što bolje iskoristiti prirodna dobra i usluge, potrebno je da tehnologije i prakse budu lokalno adaptirane i prilagođene mjestu. Takve tehnologije i prakse poteći će iz povjerljivih odnosa utjelovljenih u novim društvenim organizacijama, i novom horizontalnom i vertikalnom partnerstvu između institucija i pojedinaca. Poljoprivredni sistemi sa visokom razinom društvenih i

\footnotetext{
9 Ekološke poljoprivredne metode međunarodno su regulirane i zakonski unaprijeđen od strane mnogih država, a baziraju se uglavnom na standardima koje je postavila Međunarodna federacija pokreta organske poljoprivrede (International Federation of Organic Agriculture Movements - IFOAM), krovna organizacija za organsku poljoprivredu osnovana 1972. godine.
} 
ljudskih potencijala sposobniji su za inovaciju i prilagodbu u novonastalim situacijama poput klimatskih promjena, ili promjena u društvenoj potražnji.

Osnovni cilj ekološke poljoprivrede je optimizirati zdravlje i produktivnost međusobno ovisnih zajednica živih organizama tla, biljaka, životinja i ljudi, te se nastoji smanjiti onečišćenje okoliša i prirode, stvoriti nove socijalne i gospodarske odnose te novi odnos čovjek-priroda. Međutim, kako Cifrić (2003.) upozorava, iako je ekološka poljoprivreda uvijek održiva, nije svaka održiva poljoprivreda i ekološka (koja je samo jedna njezina varijanta). Ipak u kontekstu održivosti, "organska se poljoprivreda drži konkretnom velikom vizijom" (Cifrić, 2003.:7).

\section{Ekološke, ekonomske i sociokulturne prednosti ekološke poljoprivrede}

O održivosti se najčešće govori kroz tri dimenzije, ekološku, ekonomsku i sociokulturnu, i one su neophodne u analizi održivih ideja i/ili praksi. Ovdje nećemo ulaziti dublje u rasprave o značenju i problemima pojma održivog razvoja i održivosti, već ćemo ih za potrebe ovog rada smatrati sinonimima, a oslonit ćemo se na definiciju prema kojoj je održivi razvoj "umreženo samoobnavljanje ukupnog prirodnog i društvenog tkiva sastavljenog od njegovih ekoloških, ekonomskih i sociokulturnih slojeva, samoobnavljanje aktivnosti i aktera u kojem se razvijaju i obnavljaju priroda i društvo, danas i u sutrašnjici" (Lay, 2007.:21-22).

Iako relativno općenita, ova definicija donosi nekoliko važnih momenata koje je neophodno obuhvatiti u analizi značaja ekološke poljoprivrede i njezinih implikacija. Naime, ekološku poljoprivredu nije dovoljno promatrati samo iz ekonomističke perspektive, ona nije samo prilika za uspješno financijsko ulaganje, proizvodnju novog, zanimljivog, konkurentnog proizvoda koji može postići visoku cijenu i imati osigurano tržište već kao koncept ima širi doseg i veću društvenu vrijednost.

Ključni pojam u definiciji, ideja umreženosti i samoobnavljanja, nosi u sebi težnju ka povezanosti društvenog (ekološkog, ekonomskog i sociokulturnog) djelovanja i prirode, u smislu čuvanja neobnovljivih resursa, u smislu veće prisutnosti prirode u ljudskom životu i/ili ljudskog života u prirodi, u smislu učenja i primjenjivanja principa iz prirode u ljudskom životu, u smislu razvijanja društvene kohezije, neutraliziranje štetnih posljedica individualizma kroz učenje i razvoj zajedništva, u smislu povezivanja zajedništva, rada i ekoloških načela itd. Važnost ovog koncepta za ekološku poljoprivredu može se uvidjeti kroz njezine ekološke, ekonomske i sociokulturne aspekte.

Ekološka prednost ekološke poljoprivrede se očituje u nezagađivanju tla, vode, zraka $^{10}$, i ne zaboravimo - hrane, koju se u konvencionalnom uzgoju tretira ke-

10 Posljedice upotrebe pesticida su dalekosežne, jer otjecanjem kroz zemlju i isparavanjem postaju sastavni dio padalina čime uništavaju npr. šume u područjima možda i vrlo udalje- 
mikalijama i tijekom uzgoja i tijekom skladištenja i transporta. Zatim, ekološka prednost se očituje u tome što koncept ekološke poljoprivrede ne podrazumijeva jednake trgovačke puteve uobičajene za konvencionalno proizvedenu hranu. Pretpostavka lokalno proizvedene hrane jest izbjegavanje dalekih transportnih destinacija umjesto čega se daje prednost korištenju hrane u neposrednoj ili što bližoj okolici ${ }^{11}$. Lokalna proizvodnja hrane povećava otpornost na uvoz, što je za kontekst Hrvatske neizmjerno važno ${ }^{12}$.

Danas selo, barem načelno i u strategijama ruralnog razvoja, nije više mjesto samo poljoprivrede, nego ima i uloge koje nadilaze proizvodnju hrane, poput čuvanja tradicijske kulture i vrednota, rekreacije... Svakako, te "nove" vrijednosti ruralnog prostora ne zamjenjuju važnost poljoprivrede tj. proizvodnje hrane (Tovey, 1997.) ni za stanovnike tog prostora niti za posjetitelje, korisnike navedenih sadržaja. To samo znači, da postoje višestruke teme vezane za (predstojeće) promjene u ruralnom prostoru kojima bi se društvene znanosti trebale baviti.

Zanemarivanje pitanja hrane je produkt i političke i ekonomske realnosti ${ }^{13}$ (Tovey, 1997.). Naime, industrijalizacija ${ }^{14}$ odnosa seljak-hrana-potrošač je dovela do toga da je potrošačima sve teže uspostaviti vezu između toga što poljoprivrednici proizvode i toga što završava na njihovim stolovima (Goodman, 2004.; Tovey, 1997.).

Ekološka poljoprivreda, kao alternativna poljoprivredna inicijativa, predstavlja nadilaženje te diskrepancije koja postoji u proizvodnji i potrošnji hrane. Ekološka poljoprivreda je ideja (i praksa) koja predstavlja promjenu u razmišljanju o hrani, te nadilazi pitanje nutritivnog sastava naših obroka i postaje, kao što Fiddes (2009.) kaže, dio našeg načina života. Ona stvara drugačije društvene strukture sa specifičnim etičkim i društvenim idejama. Ekološka poljoprivreda se tiče proizvođača, potrošača, ali je i pitanje razvoja. Naime, konvencionalna poljoprivreda podrazumijeva određeni sustav proizvodnje i trgovine, s mnogo posredničkih uloga (zbog

nim od mjesta upotrebe tih istih kemikalija. Hrana iz konvencionalnog uzgoja ima manju nutritivnu vrijednost od ekološki proizvedene, a pored toga sadrže određenu količinu zaostalih kemijskih sredstava za koje se ne zna kako utječu na ljudsko zdravlje ili se barem o tome u javnoj sferi ne govori (dovoljno).

11 Time se štedi gorivo potrebno za transport, smanjuje se emitiranje stakleničkih plinova, smanjuje se trošenje vozila što zahtijeva proizvodnju novih što također indirektno utječe na emitiranje stakleničkih plinova iz industrijskih pogona. Također, time upotreba kemijskih sredstava za održavanje dugotrajne svježine proizvoda postaje izlišna... međupovezanost uzroka zagađenja i drugih štetnih utjecaja je više nego jasna.

12 Hrvatska je samodostatna u svega nekoliko proizvoda - mandarine, uljarice, svježe mlijeko, pšenica, konjsko meso (izvor: u trenutku objavljivanja ovog rada neobjavljena studija "Proizvodno-potrošne bilance i ocjena samodostatnosti poljoprivredno-prehrambenih proizvoda", MPRRR, 2009.)

13 Poljoprivrednici su poticani neovisno o kvaliteti hrane koju proizvode i neovisno o tome da li se hrana koju oni proizvedu pojede.

14 Uključujući kemizaciju te sve više genetsku modifikaciju sjemena tj. usjeva. 
masovne proizvodnje), a ekološka poljoprivreda zapravo dovodi u pitanje sustav (razmišljanja i) proizvodnje koji uzima zdravo za gotovo proizvodnju izobilja i konzumentske navike. Ona na neki način potkopava čitavu ideologiju kapitalističkog društva. Na koji način?

Vrlo često se ekološku poljoprivredu definira kao različitu od konvencionalne po onome što ona isključuje (Tovey, 1997.), no barem je jednako toliko važno govoriti o njezinom stvaralačkom momentu, o tome koje to nove stvari ona stvara, potiče, razvija.

Idejni principi inherentni ekološkoj poljoprivredi isti su oni postmaterijalistički nazori s početka rada. Oni se očituju u osmišljavanju načina za uzgoj hrane kruženjem organske tvari (obogaćivanjem zemlje kao osnovnog resursa, neštetnom i neotrovnom zaštitom biljaka), u razvijanju što direktnijih puteva između proizvođača i potrošača, u stvaranju povjerenja, solidarnosti, pravednih cijena, veće dostupnosti ekoloških proizvoda itd. Stvaranjem svijesti o sustavu proizvodnje (konvencionalnom i ekološkom te svemu što oni impliciraju) razvijaju se etički principi koji postaju sastavni dio načina života.

Ekološka poljoprivreda time predstavlja tihi otpor intenzivnoj poljoprivredi i svemu što ona nosi, te indirektan otpor korporativnom kapitalizmu.

S ekonomske strane, ekološka poljoprivreda ima karakteristike koje bi mogle predstavljati višestruke prednosti u kontekstu današnje ekonomske situacije. Ona je radno intenzivna, tj. zahtijeva mnogo više ljudskog rada nego konvencionalna poljoprivreda. Već niz godina u Hrvatskoj je stopa nezaposlenosti vrlo visoka, pogotovo u ruralnim područjima, a uz to je od ukupne poljoprivredne površine ${ }^{15}$ od 2,95 milijuna hektara (od čega je 2,15 pogodno za obradu), obrađeno svega 1,2 milijuna hektara površine (Šimleša, 2010.). Agronomskim stručnjacima je poznato da bi Hrvatska svojim kapacitetima mogla prehranjivati čitavu zemlju, a i više od toga. Svojim kapacitetima tla, vode, klime, potencijalne radne snage... no zašto tlo stoji neobrađeno, a nezaposlenima brojka raste? Hrvatsku je u vrlo maloj mjeri (ob) uhvatio na zapadu prošireniji svjetonazor ekološke etike, naturalističkih, postkapitalističkih, postmaterijalističkih vrednota. Iako postoje slojevi građana/ki koji/e razvijaju i žive takve vrednote, većina se i dalje bori sa svakodnevnim preživljavanjem, i/ili sa povećanjem životnog standarda, koji u pravilu označava posjedovanje materijalnih dobara. Kultura izobilja (Zapada), koja je rapidno ekspandirala od

15 U Strategiji gospodarenja poljoprivrednim zemljištem iz 2001. stoji podatak o 3,187,494 ha poljoprivrednog zemljišta, dok je u Upisniku poljoprivrednih gospodarstava iz 2003. dobiven je podatak o samo 1,077,404 ha (Babić, 2007.). Ta golema razlika u podacima stvara veliku pomutnju, pa tako npr. ukoliko uzmemo za točan podatak manju brojku, i podijelimo s količinom korištenog mineralnog gnojiva, dobivamo podatak koji govori da Hrvatska ima daleko najzagađenije tlo u Europi (iz rasprave na okruglom stolu Šume, tla i vode - neprocjenjiva prirodna bogatstva Hrvatske, održanog u HAZU, 12. svibnja 2011.) 
1950-ih, vjerojatno je djelomično dovela do sitosti tih društava ${ }^{16}$ visoko potrošačkim navikama, nije još zadovoljila Hrvatsko društvo u toj mjeri da bi ju se moglo odbaciti. Drugi važan razlog jest izostajanje sustavnog obrazovanja ${ }^{17}$ o ekološkoj etici i dalekosežnosti ekoloških posljedica visoko industrijaliziranog stila života i održivom razvoju. Zatim, nepostojanje težnje ka održivosti u političkim strukturama. Strategija održivog razvitka RH uglavnom je marginalan dokument u donošenju i provođenju odluka. Još jedan ekonomski razlog "za" ekološku poljoprivredu jest činjenica da prodaja ekoloških proizvoda ne doživljava pad u današnjem stanju ekonomske recesije (Ivan, 2010.).

Ruralni prostori u Hrvatskoj sve više podliježu deruralizaciji i deagrarizaciji, vitalno stanovništvo odlazi u gradove zbog nedostatka perspektive na selu te je struktura sela i seoske zajednice vrlo narušena. Stoga bi ekološka poljoprivreda možda mogla biti jedan od faktora očuvanja ruralnih zajednica i ruralne kulture i time potaknuti stvaranje nove stabilnosti društvenih i prirodnih sustava.

Modernizacijski model razvoja je oblikovao poljoprivredu u kojoj se racionalni seljak natječe s drugima, pokušava smanjiti troškove tako da se strogo specijalizira, proizvodi za agroindustrijske lance hrane i segregira se od ostalih ruralnih aktivnosti (Darnhofer, 2005.). Povećavanje troškova proizvodnje uz istovremeno stagniranje cijena, smanjuje dohodak te dio poljoprivrednika traži alternativne puteve razvoja svojih poljoprivrednih gospodarstava. Jedan od mogućih je model ruralnog razvoja u vidu npr. pomaka s proizvodnje jeftine hrane prema pružanju javnih dobara i usluga. Uključenost u prakse ruralnog razvoja dovodi do novih oblika društvene kohezije time što se stvaraju novi međuodnosi ne samo između poljoprivrednih proizvođača, već i između različitih segmenata ruralne i urbane populacije (Darnhofer, 2005.). Pritom diversifikacija djelatnosti na poljoprivrednom gospodarstvu ${ }^{18}$ može uključivati aktivnosti na poljoprivrednom gospodarstvu i izvan njega, npr. upravljanje krajobrazom, agroturizam, inovativne oblike smanjenja troškova, proizvodnju visoko kvalitetnih i regionalno specifičnih proizvoda, direktan marketing i mnoge druge. Važno je naglasiti da ne postoji stroga i nedvosmislena linija koja razgraničava prakse ruralnog razvoja i one čisto modernizacijske, što proizlazi iz pitanja predstavlja li ruralni razvoj sasvim nov, kvalitativno različit razvojni model i izvornu promjenu paradigme (Ploeg i Renting, 2004.) ili se uklapa u okvir (fleksibilne) modernizacije (Darnhofer, 2005.). U svakom slučaju, s obzirom na raznolikost praksi na gospodarstvima,

\footnotetext{
16 Naravno, ne govorimo o većini populacije u zemljama razvijenog Zapada, no ipak o znatnoj kritičnoj masi koja jest pokrenula nepotrošačke, ekološke stilove života te navela sociologe/inje i druge društvene znanstvenike/ce da se istima bave.

17 Mladih ljudi kroz sustav formalnog obrazovanja, i odraslih kroz neformalno obrazovanje te kroz sve javne institucije i medije.

18 Najčešće se pod gospodarstvom misli na obiteljsko poljoprivredno gospodarstvo (OPG) koje je po mnogim (ali ne svim autorima) viđeno kao akter sa krucijalnom ulogom u ruralnom razvoju, kao vlasnici zemlje i oblikovatelji krajobraza (Darnhofer, 2005.).
} 
uvijek se može govoriti o kontinuumu ${ }^{19}$ (ruralnorazvojnih) aktivnosti i promjena; od novih aktivnosti na obiteljskim gospodarstvima koje se mogu protumačiti kao puki dodatak u stvaranju dohotka, pa do aktivnosti koje impliciraju unutrašnje restrukturiranje i fundamentalne promjene na (obiteljskom) gospodarstvu.

Danas u Europi postoji konsenzus da poljoprivreda nije više samo dobavljač sirovina za industriju, već je poljoprivrednom politikom usvojen koncept multifunkcionalnih poljoprivrednih gospodarstava kojim se potiču različite uloge poljoprivredne djelatnosti u društvu budući da ona nudi javna dobra i usluge (Darnhofer, 2005.). Iako je, tako shvaćena, ekološka poljoprivreda postala viđena kao rješenje za probleme okoliša, dobrobiti životinja i sigurnosti hrane, a također i kao veliki doprinos ruralnom razvoju ${ }^{20}$ i time vrlo atraktivna donosiocima politika, studije (Smith i Marsden, 2004.; Banks i Marsden, 2001.) su pokazale da ekološka poljoprivreda i ideja alternativnih puteva distribucije hrane nisu uvijek lako ostvarivi, jer su često podvedeni pod mainstream mreže distribucije hrane čime gube mali poljoprivrednici i lokalni ekonomski razvoj. Darnhofer (2005.) pak tvrdi da integracija ekološke poljoprivrede u konvencionalne lance distribucije hrane ne smanjuje nužno potencijalni pozitivni utjecaj ekološke poljoprivrede na ruralni razvoj. Rezultati iz njezine studije slučaja u Austriji pokazuju da ekološka poljoprivreda može potaknuti restrukturiranje djelatnosti na poljoprivrednom gospodarstvu, što znači preusmjeravanje resursa prema širem rasponu aktivnosti, što posljedično vodi većoj uključenosti u lokalnu ekonomiju, bilo da se radi o prehrambenom sektoru ili nekom drugom. Ove nove aktivnosti mogu proširiti izvore prihoda, pa se na taj način smanjuje ovisnost poljoprivrednog gospodarstva o cijenama proizvoda. Doprinos ruralnom razvoju se tako može postići ne samo kroz alternativne puteve distribucije hrane već i kroz uključenost u tzv. parapoljoprivredne aktivnosti $^{21}$, što pokazuje studija iz Austrije. Naime, strategije poljoprivrednika koji su prešli na ekološku poljoprivredu ne oslanjaju se nužno samo na puteve distribucije hrane, već i na produbljivanje, proširivanje i restrukturiranje aktivnosti ${ }^{22}$.

19 Marsden, Banks i Bristow (2002.) navodi tri uvjeta koji određuju neku aktivnost kao dio ruralnog razvoja: prvo, da je aktivnost proizišla iz pritiska troškova i cijena, drugo, da aktivnost predstavlja novi odnos između poljoprivrednog sektora i društva u cjelini reflektirajući potrebe i očekivanja šire populacije, i treće, da aktivnost implicira redefiniranje $\mathrm{i} / \mathrm{ili}$ prekrajanje ruralnih resursa.

20 Van der Ploeg (2000.) kaže da iako se pojam ruralnog razvoja često koristi, nema općeg konsenzusa i sveobuhvatne definicije toga što se (sve) pod njim podrazumijeva.

21 Pod parapoljoprivrednim aktivnostima se podrazumijevaju transformacije na gospodarstvu u poljoprivrednim usjevima i stočarskim proizvodima, upotreba mehanizacije na drugim gospodarstvima itd, te i nepoljoprivredne aktivnosti vezane za gospodarstvo, kao što je agroturizam (Darnhofer, 2005., prema Bryden, 1992.).

22 Produbljivanje (deepening) aktivnosti se odnosi na brojne inovacije povezane s kvalitetom hrane i repozicioniranjem poljoprivrede unutar lanca opskrbe hranom; proširivanje (broadening) podrazumijeva nove nepoljoprivredne aktivnosti koje se nalaze u preklapanju društva, zajednice, krajobraza i bioraznolikosti što uključuje aktivnosti poput agroturizma, upravljanje okolišem i prirodom, proizvodnja energije i pružanje raznih usluga; prestrukturiranje (regrounding) je strategija kojom se pregrupiraju resursi na gospodarstvu 
Darnhofer (2005.) tako zaključuje da prijelaz na ekološku proizvodnju može biti ne samo motiviran ekonomskim razlozima u smislu kratkoročnog uvećavanja profita već i strategija za smanjivanje rizika, ponovno dobivanje kontrole nad resursima i povećanje kvalitete života i rada.

Ako želimo govoriti o potvrdama društvenih koristi ekološke poljoprivrede, socioloških istraživanja na tu temu manjka, a ona su svakako potrebna da bi normativna razina pristajanja uz prednosti ekološke poljoprivrede bila empirijski argumentirana, no dok se takva istraživanja ne razviju, činjenice nam mogu poslužiti za indikacije i smjer budućih istraživanja. Prema IFOAM-u (2010.), umjesto smanjivanja ${ }^{23}$ broja malih proizvođača izlažući ih zaduženjima, mala poljoprivredna gospodarstva morala bi se zaštititi, ojačati i povećati kako bi zajednice mogle same sebe održavati u budućnosti, pri čemu je ekološka poljoprivreda kao vodeći agroekološki sustav, najefikasnija i najdostupnija solucija za jačanje poljoprivrede i dostupnosti hrane. Ona stvara društveni kapital u ruralnim područjima, koristi tradicionalna znanja i promovira razmjenu između seljaka. Također, stavlja selja$\mathrm{ka}$ /poljoprivrednika u središte poljoprivredne strategije vraćajući ulogu donošenja odluka u lokalne zajednice, osiguravajući njihovo pravo da kontroliraju svoje resurse i svoje aktivno sudjelovanje u okviru stvaranja dodane vrijednosti hrani. Ona stvara otpornost i dostignuća seljačkog gospodarstva i omogućava zdraviji radni okoliš za seljake/poljoprivrednike i zajednicu. Diversificira proizvodnju čime se smanjuje utjecaj propadanja usjeva, povećava marketinške mogućnosti i poboljšava prehranu, a također povećava i usjeve, pogotovo tamo gdje je hrana najpotrebnija (IFOAM, 2010.). Primjer ekološke poljoprivrede kojom se prehranilo stanovništvo u vrijeme velike krize i neimaštine jest primjer Kube ${ }^{24}$.

Važno je napomenuti da svi proizvodi koje se danas promovira kao "zelene" ne označavaju produkte ekološke proizvodnje niti u ekološkom, niti u socijalnom smislu na koji stavljamo naglasak u ovom radu. Pojam zelenog konzumerizma, osim oksimoronske fraze, označava reklamiranje tzv. "zelenih" proizvoda i kupovanje istih na način i u mjeri kao i bilo kojih drugih proizvoda bez dubljeg promišljanja značenja zelenog proizvoda, koji bi sâm trebao imati nizak ekološki otisak (u proizvodnji, ambalaži, transportu) i ne potjecati iz nepravednih društvenih odnosa (pravedna plaća proizvođaču, neiskorištavanje radne snage). Promoviranje i kupovanje takvih (pre)skupih tzv. "zelenih" proizvoda iz pomodarstva ili p/dokazivanja

npr. relociranjem ljudskih resursa ili ponovnom upotrebom materijalnih resursa na gospodarstvu (Darnhofer, 2005.).

23 "Konvencionalna poljoprivreda odvodi ljude od njihove zemlje pretvarajući ih od ponosnih proizvođača u ekstremno siromašne i ranjive potrošače, a druge dovodi do suicida kao rezultata zaduženosti prema globalnim dobavljačima inputa u poljoprivredu" (IFOAM, 2010.).

24 O tome je šire pisao Šimleša (2010.:165-167). Također vidjeti Altieri, M. A. et al. (1999.) The greening of the "barrios": urban agriculture for food security in Cuba, u Agriculture and human values, Vol. 16, No. 2, Pg. 131-140, te Saunders, P. (2008.) Organic agriculture can feed the world, u Agronomski glasnik, Vol. 70, No. 2, PG. 123-138. 
društvenog statusa nije ništa drugo do notornog elitističkog, konzumerističkog akta (Zeman, Geiger Zeman, 2011.)

U idućem poglavlju ćemo nastaviti s primjerima ekološke poljoprivrede u zajednicama koja se na različite načine ugrađuje u društvo povećavajući njegovu otpornost (resilience) tj. neovisnost o novcu, uvozu, neobnovljivim resursima itd.

\section{Alternativni pokreti i ekološka poljoprivreda - lakmus papir za društvene vrednote}

Prema nalazima istraživanja iz $1996 .{ }^{25}$ prakse ekološke poljoprivredne proizvodnje su neodvojive od društvenih pitanja, a sežu od obnavljanja ruralnih zajednica, izbjegavanja iskorištavanja radnika, nadilaženje rascjepa između ruralnog i urbanog te proizvođača i potrošača, pa do stvaranja alternativnih životnih stilova povezivanja s drugima i s prirodom (Tovey, 1997.).

Lokalizacija hrane je proces kojim bismo mogli nazvati lokalno proizvedenu i konzumiranu hranu, što sadrži mnoge prednosti, energetske, ekološke i socijalne. Prve dvije su već spomenute, a socijalne se očituju u stvaranju povjerenja i solidarnosti - tko proizvodi hranu, na koji način, dobivaju li pravednu cijenu, tko kupuje hranu i jesu li njome zadovoljni... Ekonomsko pitanje, kao važan dio socijalnog, jest i ono o mogućnosti preživljavanja malih seljaka od njihovog rada, također vrlo aktualno pitanje za Hrvatsku, s obzirom na dugotrajnu besperspektivnost seljačkog načina života, deagrarizacije (zbog rizika propadanja gospodarstva) i deruralizacije te veliko nezadovoljstvo hrvatskih poljoprivrednika njihovim statusom te društvenim i državnim tretmanom.

Primjeri drugačijih ekonomskih sustava su lokalna partnerstva između ekoloških proizvođača i osviještenih potrošača, koja osiguravaju dobrobit za sve i potiču ponovno povezivanje ljudi sa zemljom koja ih hrani. Te lokalne mreže se nazivaju grupama solidarne razmjene ${ }^{26}$, a podrazumijevaju udruživanje bez velikih institucija. Solidarnost i povjerenje se razvijaju kroz neformalne "potrošačke zadruge ili kooperative koje područje hrane zajedno sa farmerima vraćaju u svoje ruke" (Šimleša, 2010.:143). Pristajanje na kupovinu kod lokalnih ekoloških poljoprivrednika

25 Istraživanje je nešto starijeg datuma, no prikladnost se nalazi u činjenici da je u Irskoj tada bilo nešto manje od 1\% udjela ekološke u ukupnoj poljoprivredi, kao što je to trenutno u Hrvatskoj (0,92\%, prema podacima HZPSS).

26 Postoje različiti nazivi za njih: u SAD-u je to poljoprivreda podržana od zajednice (community supported agriculture - CSA), u Italiji su to grupe solidarne kupovine (gruppi di acquisto solidale - GAS), u Francuskoj je to udruženje za održavanje seljačke poljoprivrede (association pour le maintien d'une agriculture paysanne - AMAP), u Japanu Teikei itd. U hrvatskom jeziku su ovo novi pojmovi, a izabrali smo inačicu prijevoda koji koriste članovi/ice Instituta za permakulturu (diplomirani dizajneri permakulture) jedni od prvih koji su u Hrvatskoj počeli govoriti o ovoj temi. 
i plaćanje unaprijed daje sigurnost proizvodnje, s kojom se inače teško nose zbog konkurencije velikih proizvođača i korporacija, a kupcima daje povoljnost nižih cijena koje proizvođač može ponuditi zbog sigurne prodaje, i slično ${ }^{27}$. Osim što se mijenjaju sistemi proizvodnje, javljaju se i bliže veze između seljaka/proizvođača i potrošača, kroz seljačke tržnice (Holloway i Kneafsey, 2000.), te dostavljanje povrća $^{28}$ (Deane, 2003.). S jedne strane, sve te nove društvene prakse značajne su zbog važnosti koju pridaju brizi za Z/zemlju, zbog činjenice da su manje povezane s diskreditiranom intenzivnom poljoprivredom, no s druge strane, unatoč mogućim koristima koje bi se mogle dogoditi utjecajima alternativnih praksi kao što je "Ozelenjavanje" poljoprivrede ${ }^{29}$, te mogućnosti da takvi projekti budu legitimni i financirani, poljoprivreda 21. stoljeća usvaja i "super-produktivističke" modele, kako bi se nosila s tržištem koje se iz dana u dan sve više globalizira (Halfacree, 2006.).

Pojava koja sve više pokazuje razmjere svoje održivosti su gradski i prigradski vrtovi. Prema studiji FAO 2005. godine oko 700 milijuna ljudi dobiva hranu od takvih vrtova, a hrana nije jedino što dobivaju - pritom se razvijaju zajedništvo i osjećaj pripadnosti (Šimleša, 2010.).

Gradski vrtovi ${ }^{30}$ su drugi primjer u kojem se urbana populacija okreće zemlji i većoj održivosti. Osim u zapadnoeuropskim (ili razvojno još udaljenijim) zemljama, gradski vrtovi ili vrtovi u zajednici postoje i u Bosni i Hercegovini kao nepretenciozan i neizmjerno potreban i uspješan projekt. Biobašte su se razvile iz različitih, ali povezanih društvenih potreba, pa su tako postale mjesta smanjivanja siromaštva i socijalne isključenosti, povećavanja ekonomske i političke sigurnosti, zatim mjesta hortikulturne i psihosocijalne terapije i mjesta izgradnje povjerenja, solidarnosti i zajedništva ${ }^{31}$.

27 Često je moguće direktno sudjelovanje u proizvodnji hrane, npr. pomaganje u proizvodnji hrane što se može nadoknaditi plodovima tog istog vrta kada sazriju.

28 Ovaj oblik postoji i u Hrvatskoj, u Zagrebu, gdje postoji više inicijativa: obitelj Sever je osmislila i provodi projekt Zelene eko-košare, Zadruga Naš vrt je 2010. započela organski uzgoj povrća s mogućnošću prodaje itd.

29 Kako ne bi došlo do terminološke zbrke važno je napomenuti da postoji termin "zelena revolucija" koji označava početak ere kemizirane intenzivne poljoprivrede, što je gotovo apsurdan pojam s obzirom da se tom vrstom poljoprivredne proizvodnje uništilo neizmjerno mnogo neobnovljivih prirodnih resursa, malih seoskih/seljačkih gospodarstava i lokalnih zajednica, stoga bi toj revoluciji više odgovarao "antizeleni" pridjev. Ovdje autor pod "ozelenjavanjem" smatra širenje, razvoj i mainstreaming (osvješćivanje vrijednosti i šire društveno prihvaćanje) ekološke poljoprivrede.

30 Community garden ili vrt u zajednici je bilo koji komad zemlje (privatnog ili javnog vlasništva) koji obrađuje grupa ljudi, a ne jedna obitelj ili jedna osoba. Za razliku od javnih parkova i drugih zelenih površina koje održava lokalna vlast, vrt u zajednici obično održava grupa neplaćenih ljudi ili volontera, što su najčešće sami vrtlari, stanovnici. Vrtovi u zajednici su rašireni u Italiji, Portugalu, Španjolskoj, Velikoj Britaniji, Danskoj, Rusiji, SAD, Kanadi, Australiji, Novom Zelandu, Kubi, Tajvanu... U Hrvatskoj je u studenom 2010. u Puli ispred Društvenog centra Rojc uređen prvi urbani vrt (vidi Burba, 2010.).

31 Izvor: Community Gardens Association <http://cgabih.org/bih/> 
Osim biobašti, postoje i čitave zajednice koje nastoje svojim načinom života minimalno utjecati na okoliš. Najčešće ih prepoznajemo pod pojmom "ekoselo". Ekosela su namjerne zajednice koje mijenjaju kulturne obrasce u smjeru humanizacije odnosa među ljudima i prema prirodi. Ideja ekosela te djelovanja i prakse brojnih ekosela diljem svijeta (između kojih i nekolicina u Hrvatskoj) možemo protumačiti kroz prizmu dimenzija održivosti, tim više što većina njih crpi svoju snagu upravo iz (različito nazvanih) ideja povećanja održivosti čemu većina društva, pod utjecajem globalnog klinča industrije i kapitala, ne teži. Ne ulazeći detaljnije u svaki od aspekata nastanka i djelovanja ekosela, važno je naglasiti da ona u pravilu uzgajaju svoju hranu, bez korištenja industrijskih preparata, primjenjuju i razvijaju znanje o različitim tehnikama ekološkog/organskog uzgoja (permakultura, biodinamički uzgoj...), mnoge se bave i edukacijom ${ }^{32}$ šireći time znanja o održivim praksama u uzgoju hrane, stanovanju, gradnji, transportu, korištenju energije, i ono najvažnije, o mogućnostima smanjivanja ovisnosti o sustavu - pojedinca i zajednice.

Lyson (2004.) ponovno rođenje lokalno zasnovane poljoprivrede naziva građanskom poljoprivredom (civic agriculture) jer su ove aktivnosti usko povezane s društvenim i ekonomskim razvojem zajednice. Organizacijske manifestacije građanske poljoprivrede kao što su seljačke tržnice, vrtovi u zajednici, grupe solidarne razmjene nisu praćene većinom državnih institucija, agencija, ureda itd. pa znanje i informacije o ovom novom obliku poljoprivrede i proizvodnje hrane dolazi direktno iz zajednice građanske poljoprivrede. Prema Lysonovom istraživanju (2004.) ona trenutno ne predstavlja ekonomski izazov konvencionalnoj poljoprivredi i industriji hrane, a malo je vjerojatno da će to i postati u skorije vrijeme, međutim uključuje neke inovativne načine proizvodnje, procesiranja i distribucije hrane, no svakako predstavlja održivu alternativu društveno, ekonomski i ekološki destruktivnim praksama koje proizlaze iz konvencionalne poljoprivrede. Osim toga što zadovoljava zahtjeve potrošača za svježom, sigurnom i lokalno uzgojenom hranom, ona i stvara poslove, potiče poduzetništvo i jača identitet zajednice. Ona također spaja proizvodnju i potrošnju unutar zajednica i potrošačima nudi stvarnu alternativu robi (hrani) koju proizvode, procesiraju i prodaju velike agrobiznis tvrtke.

I dok ce korporativni interesi vjerojatno nastaviti utjecati na proizvodnju hrane u smjeru povećane ekonomske globalizacije, Lyson (2004.) vjeruje da zajednice, organizacije, lokalne uprave, pa čak i pojedinci imaju na raspolaganju mnoge alate koje mogu upotrijebiti kako bi započeli promjenu i korak prema građanskijoj poljoprivredi. Nova društvena agenda za poljoprivredu dolazi odozdo umjesto odozgo. Građanski angažman u sustavu hrane javlja se diljem bogatog zapadnog, a ponegdje i deprivilegiranijim dijelovima svijeta, građani i organizacije prikupljaju hranu za gladne, permakulturni projekti koji uče siromašne kako uzgojiti hranu,

32 Spomenimo samo neke: Gaia University na nekoliko mjesta u svijetu, npr. u Ekoselu Tamera u Portugalu, zatim prostorno bliskiji primjer je: Udruga ZMAG (Zelena Mreža Aktivističkih grupa) koje već niz godina na svom Recikliranom imanju u Vukomeriću nedaleko od Zagreba održavaju radionice - teorijske i praktične iz područja ekološke poljoprivrede, gradnje, energije i različitih drugih održivih praksi. 
uspostavljaju prehrambene/poljoprivredne zadruge koja proizlaze iz zajednice, organiziraju vijeća za prehrambenu politiku. Politike i programi na lokalnoj razini a koji podupiru razvoj seljačkih tržnica, poljoprivrede potpomognute zajednicom, ekološke proizvodnje, zajedničke kuhinje, vrtove u zajednici, i sve vrste direktnog marketinga i prerade na gospodarstvu će promicati/poticati sustave proizvodnje i potrošnje koji su održiviji i naklonjeniji zajednici.

Kako objasniti širenje takvih pojava u zemljama razvijenog Zapada i većini svjetskih zemalja? Mnogi autori (Snow, Soul i Kriesi, 2004.; Foster i York, 2004., prema Ergas, 2010.; Trainer, 2002.; Schehr, 1997.) govore o ekoselima kao društvenom pokretu jer u visoko industrijaliziranoj i individualiziranoj kulturi mijenjaju društvene obrasce i strukture u području vlasništva i radni(čki)h odnosa u smjeru veće suradnje i komunalnosti (zajedništva) stvarajući ekonomije samodovoljnih susjedstava koja su uglavnom vođena lokalnom zajednicom čime se suprotstavljaju dominantnoj kulturi, njezinim institucionalnim, organizacijskim i kulturalnim autoritetima koji određuju status prema materijalnoj imovini koja zahtijeva neprekidno trošenje dragocjenih resursa. U znanstvenoj literaturi se nalaze i brojni izvori (Coffin i Lipsey, 1981.; Jacob, 1997.; Halfacree, 2007.; Halfacree, 2006.) koji govore o društvenom pokretu povratka zemlji (back to the land movement) što nam je u ovom kontekstu značajno, bez obzira što pojam društvenog pokreta u sociologiji nije jednoznačan ${ }^{33}$, jer govorimo o njemu kao novoj društvenoj pojavi koja se na različite načine širi u društvenom prostoru i vremenu ukazujući na procese promjena u vrijednosnim paradigmama. "Povratak zemlji" znači samodovoljan život blizak prirodi i jednostavnosti, a daleko od konzumerizma, a osnovna pretpostavka je život u ruralnom/ijem području i vlastita proizvodnja hrane koja je prema istraživanju Jacoba i Brinkerhoffa (1999.) najvažnija od istraženih vrednota "povratnika zemlji", iza čega slijede proizvodnja energije, edukacija vlastite djece itd.

Karakteristično za takve zajednice (i pokrete) nije težnja da se promijeni svijet izvan sebe i svoje neposredne okoline, već stav i svijest da je osobno ujedno i politički, čime način života (održiv, ekološki i socijalno osviješten u svim izborima koje čovjek čini) postaje političko uvjerenje i aktivizam. Tovey (1997.) je od sudionika/ca svog istraživanja dobila upravo takve odgovore, koji ekološku poljoprivredu navode ne samo kao prehrambenu orijentaciju, životni (ili trenutni) poziv ili izvor prihoda, već i kao politički stav. U istom istraživanju sudionici/e navode da preferiraju neovisnost od države i tržišnih struktura, slobodnije komunitarne radije nego formalne i hijerarhijske načine međusobne organizacije (npr. Život izvan kapitalizma) što je na tragu određenja društvenog pokreta prema ranije spomenutim autorima. U svakom slučaju, ekološka poljoprivreda dio je civilne faze ekološkog

33 Nejednoznačnost pojma se odnosi na postojanje dvije glavne tradicije tumačenja društvenog pokreta u sociologiji, a izostanak jedne integralne teorije i/ili konsenzusa. Jedna je teorija mobilizacije resursa koja je orijentirana na političku dimenziju i formalne organizacijske manifestacije društvenih pokreta; a druga je kulturalna perspektiva prema kojoj društveni pokreti najduže opstaju u neformalnim kulturalnim mrežama (Melucci, 1989., prema Tovey, 2002.) unutar kojih se stvaraju nove društvene veze i životni stilovi (Tovey, 2002.). 
pokreta što znači da ekološka politika postaje decentralizirana s težištem na lokalnim zajednicama i lokalnim i pojedinačnim inicijativama jer se uviđa da ekološki problemi (i shvaćanje istih) postaju globalni, a da se s globalne razine ne mogu riješiti (Mesić, 1998.). To podrazumijeva da se "borba" za ekološki(ji) način života širi ne samo kroz političke akcije i strukture nego i kroz mijenjanje životnih navika pojedinaca i malih grupa osviještenih o zamahu ekoloških problema i potrebi da se takvo stanje promijeni. Stvaranje održivog načina života, i bez revolucionarnih pobuna, posredno mijenja vrijednosne principe jednog dijela društva koji postaju primjer prakse održivosti.

\section{Ekološka poljoprivreda u svijetu i Hrvatskoj}

Prednosti organskog uzgoja hrane prepoznaju farmeri i države diljem svijeta. Na to ukazuje stalni porast tržišta ekološkom hranom, i obradivih površina na kojima se uzgaja organski. U Hrvatskoj je ekološka poljoprivreda zakonski regulirana tek nedavno; 2001. godine ${ }^{34}$ kada je donesen Zakon o ekološkoj proizvodnji koji je u skladu sa regulativama EU i IFOAM-a.

Najveći udio u svjetskim površinama pod ekološkim uzgojem imaju Oceanija i Australija (42\%), zatim Europa (24\%) i Latinska Amerika (16\%) (IFOAM, 2008.). Ako govorimo o zemljama s certificiranim zemljištem pod ekološkim uzgojem, na svjetskom vrhu su Falklandski otoci, Lihtenštajn, Austrija, Švicarska, Švedska.

Slika 1.

Top 10 država sa najvišim udjelom površina pod organskim uzgojem 2008.

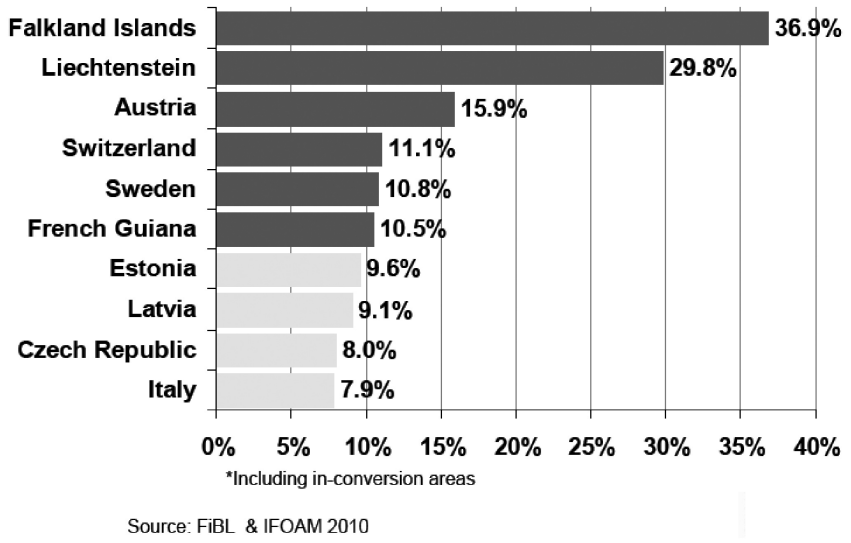

34 Europska unija je područje ekološke poljoprivrede zakonski regulirala još 1992. godine. Godine 2010. u Hrvatskoj je donesen novi Zakon o ekološkoj proizvodnji i označavanju ekoloških proizvoda. 
Slika 2.

Ekološko poljoprivredno zemljište 2008.

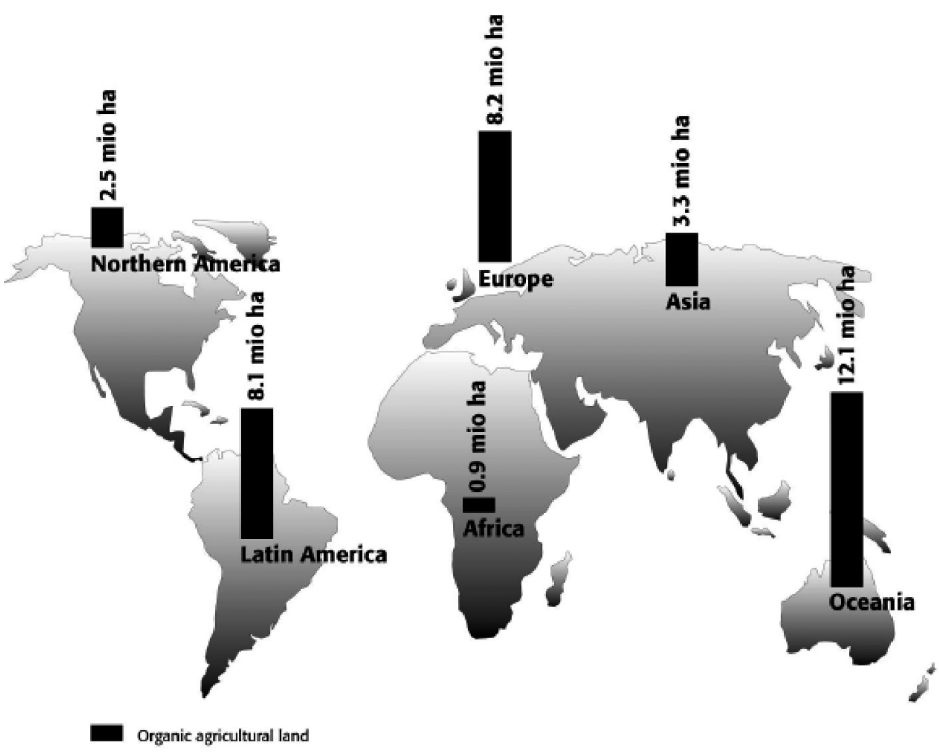

Izvor: http://www.organic-world.net/graphs-maps.html

Bitno je naglasiti da ovo nisu konstantne brojke, odnosno da udio obradivih površina pod organskim uzgojem neprestano raste u svim zemljama. Radi se o tržištu koje je još uvijek nezasićeno, potražnja premašuje proizvodnju čak i u doba recesije, tako da su mnoge zemlje (primjerice zapadne Europe) primorane uvoziti eko proizvode.

Prema zadnjim podacima IFOAM-a iz veljače 2010., u 2008. godini ekološku poljoprivredu prakticiralo je 1,4 milijuna certificiranih proizvođača, iz 154 od 196 zemalja svijeta na ukupnoj površini od 35 milijuna hektara. U odnosu na godinu ranije to iznosi prosječni porast od devet posto, a od 2000. porast iznosi 118 posto. Svjetsko tržište eko proizvoda je krajem 2010. godine iznosilo gotovo 60 milijardi USD, čime se njegova vrijednost učetverostručila u odnosu na stanje prije deset godina.

Sredinom 1980-ih godina certificiranih površina pod ekološkom poljoprivredom u Europi bilo tek nekih stotinjak tisuća hektara. Od 1990-ih godina kao rezultat donošenja Uredbe Europske komisije broj 2092/91, ekološka poljoprivreda počela se ubrzano razvijati gotovo u svim europskim državama, a posebno u državama članicama Europske unije (Akcijski plan, 2010.). Godine 2008. u EU se na ekološki način obrađuje preko osam tisuća hektara, što predstavlja više od četiri posto udjela u ukupnim poljoprivrednim površinama EU, pri čemu Italija, Španjolska i Njemačka zajedno imaju više od 40 posto ekoloških poljoprivrednih površina. Europsko tržište ekoloških proizvoda je najveće svjetsko tržište procijenjeno na 26 milijardi USD 2008. godine (http://www.organic-world.net). 
Što se predviđanja tiče, Kisić (2009.) tvrdi da sadašnje stanje hrvatske poljoprivrede ne dopušta optimistične prognoze za razvoj ekološke poljoprivrede, iz nekoliko razloga - slaba obrazovna struktura hrvatskih poljoprivrednika, odlazak vrhunskih i iskusnih agronoma nakon kolapsa bivšeg poljoprivredno-industrijskog sustava ${ }^{35}$, smatrajući da nikakve potpore ne mogu nadoknaditi njihovo znanje (Kisić, 2009.). Kisić smatra da ne može biti razvoja ekološke bez razvoja konvencionalne (održive) poljoprivrede. Nasuprot tome, Badgley et al. (2007.) su na 293 primjera usjeva istražili prosječne količine uroda u ekološkom i konvencionalnom uzgoju (za razvijene i zemlje u razvoju) te na temelju toga modelirali globalne zalihe hrane koje bi se mogle ekološki uzgojiti na sadašnjem poljoprivrednom tlu. Modelom je procijenjeno da bi se ekološkom proizvodnjom moglo proizvesti dovoljno hrane na globalnoj razini da se održi sadašnja svjetska populacija, a potencijalno i veća, bez povećanja poljoprivrednog zemljišta. Unatoč rastu interesa i potencijalima poput relativno čistih i nedirnutih prirodnih resursa te više od 36\% neobrađenih obradivih površina, idealnih za stavljanje u ekološku proizvodnju, Hrvatska prelazi tek jedan posto takve proizvodnje (točnije 1,29\%36 udjela u ukupnoj obrađenoj površini prema podacima Ministarstva poljoprivrede, ribarstva i ruralnog razvoja, prema zadnjim službenim podacima iz 2010.), te ulazi u skupinu rijetkih europskih zemalja u kojima je ovaj vid poljoprivredne proizvodnje još uvijek pretežno nerazvijen ${ }^{37}$. U ovom trenutku mali broj hrvatskih proizvoda može nositi znak "eko", što Hrvatsku stavlja daleko iza njenih srednjeeuropskih i sredozemnih susjeda. Razlozi za ovakvo stanje su mnogobrojni; od donedavno nedovoljno poticajne poljoprivredne politike, nedovoljne obrazovanosti i informiranosti proizvođača, neorganiziranosti plasmana proizvoda, te nedovoljno razvijene ekološke svijesti potrošača. Ipak, činjenica je da broj hrvatskih ekoloških proizvođača neprestano raste, te da je u listopadu ${ }^{38}$ 2011. godine registrirano ukupno 1470 ekoloških i 599 proizvođača integrirane poljoprivredne proizvodnje. Tome je zasigurno doprinijela posljednjih godina poticajna poljoprivredna politika spram ekološke proizvodnje hrane.

Kako bi Hrvatska mogla bolje slijediti pozitivan primjer Europske Unije, mora preuzeti i primijeniti njezina pozitivna iskustva. Prije svega ovdje mislimo na stalnu i neprikrivenu financijsku potporu ekološkoj poljoprivredi, stabilan pravni okvir i stvarna pravna zaštita od nelojalne konkurencije konvencionalnih proizvođača,

35 Nakon raspada socijalističkog sustava, u Hrvatskoj se promijenila politika prema poljoprivrednoj proizvodnji, pa su se nekadašnji agrokombinati i PIK-ovi rasformirali, čime su stručnjaci koji su u njima radili postali "suvišni".

36 Prema neslužbenim podacima iz MPRRR (Agencije za plaćanje u poljoprivredi, ribarstvu i ruralnom razvoju) početkom listopada 2011. postotak se povećao na 3,33\% ekoloških i 5,9\% integriranih površina, s mogućnošću smanjenja od oko 10\% zbog kontrole koju trenutno na terenu provodi MPRRR.

37 Iako je povećanje površina ekološke proizvodnje u posljednjih godinu dana veće od 150\% (uzimajući u obzir zasad neslužbene podatke).

38 Stanje na dan 3. listopada 2011. (MPRRR, Agencija za plaćanje u poljoprivredi, ribarstvu i ruralnom razvoju). 
provedbu nacionalnog akcijskog plana razvoja ekološke poljoprivrede, te razvijanje dobro informiranog tržišta za certificirane eko proizvode.

U sklopu čimbenika koji su bitni za razvoj ekološke poljoprivredne proizvodnje Kutler razlikuje unutarnje i vanjske čimbenike (Renko i Bošnjak, 2009.). U vanjske čimbenike se ubrajaju demografski, gospodarski, politički, sociokulturni i mikroekonomski. U unutarnje čimbenike ubrajaju se marketing, financije, proizvodnja i organizacija. Analizom ovih čimbenika može se zaključiti kako postoje mnoge predispozicije u Hrvatskoj za jači razvoj ekološke poljoprivrede poput organizacijske fleksibilnosti malih proizvođača, otvaranje tržišta ulaskom u EU, pozitivan imidž Hrvatske kao zemlje s očuvanom prirodom, te velika količina neobrađenih obradivih površina. Međutim, dok neki autori (Čuka, 2003.) ističu iznimno povoljne prirodno-geografske uvjete za razvoj ekološke poljoprivrede, istovremeno zanemaruju sociokulturne i mikroekonomske prepreke koje nije lako nadići. Dakle, osim potencijala, postoje i zapreke razvoju ekološke proizvodnje u Hrvatskoj - da nabrojimo samo neke: negativni demografski trendovi, nedovoljna informiranost i zainteresiranost potrošača, nedostatak tradicije ovakve proizvodnje, nedovoljna educiranost (potencijalnih) proizvođača, nedostatak ekološkog senzibiliteta svih uključenih strana, često vrlo mali početni kapitala kod proizvođača, proizvodnja uglavnom primarnih sirovina, mali prerađivački kapaciteti, te neodvojenost istih ${ }^{39}$.

2010. je donesen i Akcijski plan razvoja ekološke poljoprivrede i proizvodnje hrane u Hrvatskoj 2011. - 2016. godine ${ }^{40}$ čija svrha je poticanje što bržeg razvoja ekološke poljoprivrede i proizvodnje hrane, te u sklopu kojeg je izrađena i SWOT analiza. Spomenuti Akcijski plan predviđa konstantan porast udjela površina pod ekološkom poljoprivredom do krajnih $8 \%$ do 2016. godine. Iako iz sadašnje pozicije to izgleda kao ambiciozan plan, vrijedno je podsjetiti da će takvim tempom rasta 2010. godine Hrvatska dostigla razinu Mađarske iz 2008., Grčke u 2013., Slovenije u 2015., a Slovačke, Italije i Češke u 2016. godini. U ovom svjetlu projiciranih 8\% ne čini se tako ambicioznim i neostvarivim planom, te bi sa $8 \%$ udjela Hrvatska još uvijek imala dvostruko manje udjela od Austrije koja je još 2008. Imala 16\% ekološki obrađenih površina (Akcijski plan, 2010.).

SWOT (Strengths-snage /Weakneses-slabosti /Opportunities-mougćnosti /Threats -opasnosti) analiza uzela je u obzir politički, institucionalni i pravni okvir, ljudske

39 Renko i Bošnjak (2009.) navode kako većina proizvođača ekoloških proizvoda u Hrvatskoj proizvode isključivo primarnu sirovinu kojom onda zadovoljavaju vlastite potrebe finalizacije proizvoda. Tržište primarnih proizvoda ne postoji, tako da dolazi do nužnosti uvoza tih proizvoda.

40 U sklopu hrvatsko-njemačke bilateralne tehničke suradnje Savezno ministarstvo za gospodarsku suradnju i razvoj Savezne Republike Njemačke i GTZ u suradnji s Ministarstvom poljoprivrede, ribarstva i ruralnog razvoja Republike Hrvatske provode projekt pod nazivom "Poticanje gospodarstva i zapošljavanja u prehrambenom sektoru". Treća faza provedbe spomenutog projekta obuhvaća i izradu Akcijskog plana razvoja ekološke poljoprivrede u Republici Hrvatskoj od 2011. do 2016. godine. 
resurse, prirodne resurse, tržište i promociju, te regionalne snage. Popis slabosti je puno dulji od popisa snaga, ali nasuprot tome postoje brojne mogućnosti koje su navedene u analizi.

Krenimo redom. Unatoč postojanju brojnih nacionalnih razvojnih strategija, programa i akcijskih planova koji prepoznaju važnost ekološke poljoprivrede, ne postoji nikakav vid institucionalne suradnje između pojedinih ministarstava. Ne samo to, postoji i određeni rivalitet između resornih ministarstava, te zloporaba termina "eko" u dnevne promidžbene političke svrhe. Na popis negativnih trendova u političko-institucionalnom okviru možemo dodati i centraliziranost odlučivanja i financijske moći, nepostojanje suradnje između nacionalnih i regionalnih tijela, pretjeranu administraciju, neusklađenost propisa i zakona, te nesrazmjer u regionalnom pristupu potporama ekološkoj poljoprivredi. Kako bi odgovorio na ove probleme i potrebe, Akcijski plan predviđa niz detaljno razrađenih mjera od osnivanja nacionalnih i regionalnih koordinacija za provedbu Akcijskog plana, usklađivanje hrvatskog pravnog okvira s okvirom EU, osiguranje (većih) novčanih poticaja, i sl.

Prirodni resursi za razvoj ekološke poljoprivrede nedvojbeno u Hrvatskoj postoje. SWOT analiza akcijskog plana ističe kao bitnu prednost postojanje zapuštenih ekološki čistih poljoprivrednih površina pogodnih za razvoj ekološke poljoprivrede, bogatstvo kulturno-povijesne i prirodne baštine, velik broj zaštićenih prirodnih površina, te velik broj šumskih površina. Međutim, iako su prirodni resursi u Hrvatskoj ocijenjeni kao relativno čisti i nedirnuti (uglavnom zahvaljujući napuštanju sela), sve više su ugroženi uporabom kemijskih zaštitnih sredstava i mineralnih gnojiva u konvencionalnoj poljoprivredi, te prenamjenom poljoprivrednog zemljišta u građevinsko, čime se ozbiljno ugrožava biološka raznolikost ${ }^{41}$. Velika ograničenja bržem razvoju ekološke prirode također su prepoznata u velikoj rascjepkanosti posjeda, te neriješenim vlasničkim odnosima; također nedostatak volje i sposobnosti državne uprave da se ti problemi legalno i financijski riješe.

Ljudski resursi za razvoj ekološke poljoprivrede postoje, od entuzijastičnih ekoloških proizvođača do vjernih potrošača. Akcijski plan naglašava kako glavnu skupinu u sektoru ekološke proizvodnje čine mladi educirani ljudi čiji su životni stil i filozofija u skladu sa ekološkim načelima. Ograničavajući čimbenici s druge strane, su dugogodišnji trend depopulacije i senilizacije ruralnog prostora, nepovoljna obrazovna struktura seoskog stanovništva i nedostatak kvalitetne radne snage za ekološku poljoprivredu. SWOT analiza Akcijskog plana između ostalog upozorava i na nedostatnost opće razine informiranosti i edukacije o ekološkoj poljoprivredi ${ }^{42}$, te na očit nedostatak stručno-znanstvenih projekata u ekološkoj

$\mathbf{4 1}$ Hrvatska je bogata velikim brojem autorhonih i endemskih vrsta biljaka i životinja, ali još uvijek nije izradila sustav banaka gena autohtonih sorata poljoprivrednih biljaka i zaštićenih pasmina životinja.

42 U Akcijskom planu navodi se da iako hrvatska javnost i mediji imaju općeniti pozitivni stav o ekološkoj poljoprivredi, opće razina edukacije i informiranosti još uvijek je nedo- 
poljoprivredi. Neke znanstvene institucije pokazuju interes za istraživanje u ekološkoj poljoprivredi, ali im nedostaje iskustvo i znanje, dok su druge iz istog razloga prema njoj podozrive.

Daljnje slabosti u navedenoj SWOT analizi su: visoki troškovi ekološke proizvodnje uz upitnu profitabilnost, postojanje "kulture" neplaćanja među gospodarskim subjektima u Hrvatskoj, nedostupnost kapitala za ulaganje, te neorganiziranost tržišta i sl.

Spomenuli smo da unatoč mnogim preprekama ipak ima razloga za optimizam, pa i brojnih mogućnosti za razvoj ekološke poljoprivrede, što pokazuje i SWOT analiza. Uspostavljanja koordinacije između relevantnih ministarstava, suradnja istih sa konzultantskim kućama, zadržavanje, odnosno povećanje postojećih poticaja, te veće korištenje predpristupnih fondova Europske unije, zasigurno bi dalo potreban vjetar u leđa razvoju ekološke poljoprivrede.

Kako su prirodni resursi već tu, relativno očuvani i nedirnuti, potrebno bi ih bilo zaštiti od moguće devastacije u budućnosti ${ }^{43}$. Poticanjem malog i srednjeg poduzetništva u ekološkoj poljoprivredi otvorila bi se radna mjesta, pomogao sačuvati lokalni kulturni identitet, te revitalizirati ruralna područja. Kako je ekološka poljoprivreda u Hrvatskoj nedovoljno razvijena djelatnost sa svih aspekata, dobrodošli su napori civilnog društva, ali i znanstveno istraživanje i znanstvenotehnički projekti.

Dosadašnja praksa pokazala je da se ekološka poljoprivreda financijski isplati; i u Hrvatskoj i u svijetu tržište je nezasićeno ekološkim proizvodima, što znači da kupci tih proizvoda postoje, te da problem leži negdje drugdje. Prelazak s konvencionalne na ekološku poljoprivredu nije niti lagan niti jednostavan. U načinu proizvodnje i distribucije hrane, prehrambenim stilovima i navikama ogleda se smjer društvenog razvoja i vrednote koje stoje u temelju tih izbora. U tom smislu, Hrvatsku bismo mogli okvalificirati kao neproizvođačku, uvozno-ovisnu, tehnološki konzervativnu, konvencionalno usmjerenu zemlju koja bi svoju komparativnu prednost očuvane i relativno čiste zemlje mogla upotrijebiti kao dragocjeni resurs...

statno razvijena. Potrošači nisu upoznati s prednostima ekološke poljoprivrede, osobito većoj nutritivnoj kakvoći eko-proizvoda. Slabo razumijevanje prirode ekoloških proizvoda te potrošače navodi da sve lokalno proizvedene proizvode poistovjećuju sa ekološkim proizvodima.

$\mathbf{4 3}$ Ulaskom u Europsku uniju Hrvatska postaje dio programa NATURA 2000. Kako bi bila spremna sudjelovati u spomenutom programu, Hrvatska je već započela pripreme selekcije područja za zaštitu. U tu svrhu donesena je Uredba o proglašenju ekološke mreže Republike Hrvatske koja obuhvaća visokih 49\% kopnenih površina, odnosno postojanje cjelovitog pravnog okvira koji će znatno olakšati održivi razvoj ruralnih područja putem ekološke poljoprivrede. 


\section{Zaključak}

Zašto su brojni rezultati koji pokazuju prednosti ekološke poljoprivrede zanemareni i nisu u većoj mjeri zaživjeli u praksi i načinu razmišljanja? Jedan od razloga je vjerojatno nasljeđe redukcionizma koje koči znanost i mnoge pokušaje holističkog razmišljanja. Francis (2009.) apostrofira da je holističko razmišljanje naspram redukcionističkom naprosto prekompleksno i da je većini znanstvenika naprosto lakše baviti se analizom pojedinih faktora (npr. u usporedbi konvencionalne i ekološke poljoprivrede, ili monokulturnog i sistema raznovrsnih usjeva (multiple cropping), ili pak globalnog i lokalnog sustava hrane) jer je uzimanje u obzir svih ekonomskih, prehrambenih, ekoloških i društvenih faktora zajedno prezahtjevno, a možda i (kvantitativno) nemoguće. Dodatno, a možda i važnije objašnjenje jest "Kuhnova" paradigma (Francis, 2009.). Ako monokulturni uzgoj i čitav sustav konvencionalne poljoprivrede, zajedno sa ekonomističkim ciljevima i globalnim tržištem shvatimo kao dijelovima iste (znanstvene) paradigme, onda ne čudi da mnogi argumenti, pa makar i znanstveno potvrđeni, "protiv" tih praksi ne znače da će one biti odbačene. Nove znanstvene spoznaje o štetnosti konvencionalne, a višestrukoj prikladnosti ekološke poljoprivrede se naprosto ne uklapaju u sustav važećih istina, u paradigmu.

Ipak, zahtjevi za organskom hranom rastu iz mnogih razloga: sigurnosti hrane, prehrane, kvalitete okoliša i socijalne pravednosti. Iako joj korijene možemo naći još 20-ih godina prošlog stoljeća, ekološka poljoprivreda razvijala se sporo, i vrlo se teško nosila u borbi na tržištu sa industrijskom. Ipak, u posljednje vrijeme ekološka poljoprivreda postaje sve popularnija: ne samo kao obilježje individualnog životnog stila, nego kao "važan segment postmodernog ekološkog svjetonazora koji promovira holističku percepciju svijeta, ekocentričnu etiku, te konsekventnu ekološki osviještenu praksu" (Geiger, Zeman, 2010b.:234).

Godine 2008. UN-ov Program za okoliš (UNEP) i UN-ova Konferencija o trgovini i razvoju zajednički izjavljuju kako "organska poljoprivreda može biti učinkovitija u osiguravanju sigurne opskrbe hranom u Africi, nego bilo koji konvencionalni sustav poljoprivredne proizvodnje, te je vjerojatnije da će biti dugoročno održiva"; također "urodi su se više nego udvostručili gdje je prakticirana organska poljoprivreda, a plodnost tla i otpornost na sušu su se poboljšali".

Globalno gledajući sektor ekološke hrane je najbrže rastući sektor proizvodnje hrane. U povećanoj potražnji za ovakvim načinom uzgoja hrane prepoznaje se premještanje inicijalnog fokusa sa okolišnih aspekata održive ekološke poljoprivrede na uključivanje ekonomskih, ali i šire političkih i društvenih dimenzija.

Sa znanstvenog i sociološkog aspekta potrebna su nam istraživanja svih u radu navedenih mogućih sociokulturnih i socioekonomskih utjecaja ekološke poljoprivrede na društvo. Daleko od toga da je znanstvena empirijska provjera jedini faktor koji utječe na stav javnosti i primjenu određene prakse, no bez nje društveno pridan legitimitet bilo koje ideje jest upitan. Opravdanost, ili ekonomskim rječni- 
kom - konkurentnost, ekološke poljoprivrede je dokazana mnogim istraživanjima u kojima se zaključuje da su prinosi iz ekološkog uzgoja uglavnom isti ili veći od onih u konvencionalnom uzgoju. Međutim, ono što dosad nije znanstveno potvrđeno i sociološki je neophodno istražiti jesu društvene implikacije i/ili posljedice ekološke poljoprivrede - da li i na koji način ekološka poljoprivreda potiče ruralni razvoj, kako utječe na (ne)zaposlenost, dostupnost hrane, na zdravlje ljudi i okoliša, na otpornost, samodovoljnost i samostalnost u odlukama (i održivost) poljoprivrednih/seljačkih gospodarstava i lokalnih zajednica, kako utječe na kulturnu baštinu i identitet lokalnih zajednica, kako utječe na socijalni kapital, solidarnost i povjerenje u zajednicama... Kako različiti društveni aranžmani u kojima se javlja ekološka poljoprivreda kao okosnica (dijapazon primjera građanske poljoprivrede) utječu na socijalnu održivost (gore navedenu kroz pojmove solidarnosti, povjerenja, kohezije itd.). U tom smislu, potrebna su nam sociološka i interdisciplinarna istraživanja, jednako kvalitativna i kvantitativna, da bi se obuhvatila većina "nevidljivih", a možda društveno vitalnih značajki napretka prema socijalnoj pravednosti, društvenoj koheziji, a time i integralnoj održivosti.

\section{Literatura}

1. Akcijski plan razvoja ekološke poljoprivrede u Republici Hrvatskoj 2011.-2016. godine (2010). U sklopu programa "Poticanje gospodarstva i zapošljavanja u prehrambenom sektoru". Ministarstvo za gospodarsku suradnju i razvoj SR Njemačke i Ministarstva poljoprivrede, ribarstva i ruralnog razvoja Republike Hrvatske.

2. Babić, B. (2007). Koliko Hrvatska ima obradive zemlje?. Poslovni dnevnik, 7. siječnja 2007. Pregledano 27. svibnja 2011. (http://www.poslovni.hr/vijesti/koliko-hrvatskaima-obradive-zemlje-30651.aspx).

3. Badgley, C.; Moghtader, J.; Quintero, E.; Zakem, E.; Chappell, M. J.; Avilés-Vázquez, K.; Samulon, A.; i Perfecto, I. (2007). Organic agriculture and the global food supply. Renewable Agriculture and Food Systems, 22: 86-108. Pregledano 5. Listopada 2011. (http://journals.cambridge.org/action/displayAbstract;jsessionid=15C5865304CBBB085 8CD94F0CA2273DE.journals?fromPage $=$ online $\&$ aid $=1091304)$.

4. Banks, J. i Marsden, T. (2001). The nature of rural development: the organic potential. Journal of Environmental Policy and Planning, 3(2):103-121.

5. Best, H. (2008). Organic agriculture and the conventionalization hypothesis: a case study from West Germany. Agriculture and Human Values, 25:95-106.

6. Burba, I. (2010). Niknuo urbani vrt u Rojcu. Komunikacijska platforma ekologija.hr. Udruga Zelena Istra. Pregledano 29. svibnja 2011. (http://ekologija.hr/index.php?id= 166\&tx_ttnews[tt_news] $=1217 \& \mathrm{tx} \_t$ tnews[backPid] $\left.=167 \& \mathrm{cHash}=4 \mathrm{f} 83 \mathrm{a} 883 \mathrm{ab}\right)$.

7. Cifrić, I. (2003). Značaj iskustva seljačke poljoprivrede za ekološku poljoprivredu. Sociologija i prostor, 41(1/2):5-27.

8. Cifrić, I. (1994). Napredak i opstanak: moderno mišljenje u postmodernom kontekstu. Zagreb: Hrvatsko sociološko društvo.

9. Coffin, R. J. i Lipsey, M. W. (1981). Moving Back to the Land: An ecologically responsible lifestyle change. Environment and Behavior, 13(1):42-63.

10. Čuka, A. (2003). Ekološka poljoprivreda: prati li Hrvatska svjetske trendove?. Zagreb: Hrvatsko geografsko društvo. Pregledano 15. svibnja 2011. (http://www.geografija.hr/ clanci/212/ekoloska-poljopriveda-prati-li-hrvatska-svjetske-trendove). 
11. Darnhofer, I. (2005). Organic farming and rural development: Some evidence from Austria. Sociologia Ruralis, 45(4):308-323.

12. Deane, T. (2003). Green Box. Resurgence, 219:14-15.

13. De Schutter, Olivier (2010). Agroecology outperforms large-scale industrial farming for global food security. Pregledano 3. Listopada 2011. (http://www.srfood.org/images/ stories/pdf/press_releases/20100622_press_release_agroecology_en.pdf).

14. Douwe, J.; Ploeg, J. D. van der i Renting, H. (2004). Behind the "Redux": A Rejoinder to David Goodman. Sociologia Ruralis, 44(2):234-242.

15. Ergas, C. (2010). A Model of Sustainable Living: Collective Identity in an Urban Ecovillage. Organization \& Environment, 23(1):32-54.

16. Fiddes, N. (2009). Meso: prirodni simbol. Zagreb: Jesenski i Turk.

17. Francis, C. A. (2009). Conventional research on controversial issues: an exercise in futility. Renewable Agriculture and Food Systems, 25(1):3-7.

18. Geiger, M. i Zeman, Z. (2010a). Uvod u sociologiju (održivih) zajednica. Zagreb: Institut društvenih znanosti Ivo Pilar.

19. Geiger, M. i Zeman, Z. (2010b). Hrana kao svjetonazor: sociološki aspekti organske poljoprivrede $i$ "zdrave hrane". Opatija: Izlaganje na 5. Međunarodnom Simpoziju agronoma, 15.-19. veljače, 2010. Pregledano 6. Listopada 2011. (http://sa.agr.hr/pdf/2010/ sa2010_p0209.pdf).

20. Goodman, D. (2004). Rural Europe Redux? Reflections on alternative agro-food networks and paradigm change. Sociologia Ruralis, 44(1):3-16.

21. Halfacree, K. (2007). Back-to-the-land in the Twenty-First Century - making connections with rurality. Tijdschrift voor Economische en Sociale Geografie, 98:3-8.

22. Halfacree, K. (2006). From dropping out to leading on? British counter-cultural backto-the-land in a changing rurality. Progress in Human Geography, 30:309-336.

23. Holloway, L. i Kneafsey, M. (2000). Reading the space of the farmers' market: a case study from the United Kingdom. Sociologia Ruralis, 40(3):285-299.

24. IFOAM(2010). OrganicAgriculture-TheAffordablePathwaytoTacklingHunger.Pregledano 5. listopada 2011. (http://www.ifoam.org/press/press/2008/20101012_Launch_of_ Food_Security_Campaign_WFS_Rome.php).

25. IFOAM (2008). Global Organic Farming: Continued Growth-IFOAM, FiBL and SÖL present new facts and figures about the organic sector at BioFach 2008. Pregledano 5. listopada 2011. (http://www.ifoam.org/press/press/2008/20080221_statistic.php).

26. Ivan, T. (2010). Tržište koje raste: ekološka proizvodnja. Geo (podlist Financijski vodič), Studeni, 2010.

27. Jacob, J. C; Brinkerhoff, Merlin B. (1999). Mindfulness and subjective well-being in the sustainability movement: A further elaboration of multiple discrepancies theory. Social Indicators Research, 46(3):341-368.

28. Jacob, J. C. (1997). New Pioneers: The Back-to-the-Land Movement and the Search for a Sustainable Future. Penn State University Press.

29. Kisić, I. (2009). Ekološka poljoprivreda u Hrvatskoj: stanje i predviđanja. Agronomski glasnik, 70(6):591-592.

30. Kloppenburg, J. (1991). Social theory and the deconstruction of agricultural science: Local knowledge for an alternative agriculture. Rural Sociology, 56(4):519-548.

31. Kušen, E. (2003). Uređenje, razvoj i obnova hrvatskog ruralnog prostora: prostorni, gospodarski i sociokulturni okvir za razvoj ekološke poljoprivrede. Sociologija i prostor, 41(1/2):29-45.

32. Lay, V. (2007). Razvoj sposoban za budućnost: prilozi promišljanju održivog razvoja Hrvatske. Zagreb: Institut društvenih znanosti "Ivo Pilar".

33. Lyson, T. A. (2004). Civic agriculture: reconnecting farm, food, and community. Lebanon: Tufts University Press. 
34. Marsden, T.; Banks, J. i Bristow, G. (2002). The social management of rural nature: Understanding agrarian-based rural development. Environment and Planning, 34(5):809-825.

35. Mesić, M. (1998). Nastanak i razvoj američkog ekološkog pokreta. Socijalna ekologija, 7(1/2):91-114.

36. Motik, B. i Šimleša, D. (2007). Zeleni alati za održivu revoluciju. Zagreb: Što čitaš, ZMAG.

37. Ploeg, J. D. van der (2000). Revitalizing agriculture: farming economically as starting ground for rural development. Sociologia Ruralis, 40(4):497-511.

38. Ploeg, J. D. van der i Renting, H. (2004). Behind the "redux": A rejoinder to David Goodman. Sociologia Ruralis, 44(2):233-242.

39. Pretty, J. (2009). Can Ecological Agriculture Feed Nine Billion People?. Monthly Review, 61(6). Pregledano 1. svibnja 2011. (http://www.monthlyreview.org/091123pretty.php).

40. Renko, S. i Bošnjak, K. (2009). Aktualno stanje i perspektive budućeg razvoja tržišta ekološke hrane u Hrvatskoj. Ekonomski pregled, 60(7/8):369-395.

41. Schehr, R. C. (1997). Dynamic Utopia: Establishing Intentional Communities as a New Social Movement. Westport: Bergin \& Garvey, an imprint of Greenwood Publishing Group.

42. Shiva, V. (2002). Protect or Plunder?: Understanding Intellectual Property Rights. New York: Zed Books.

43. Smith, E. i Marsden, T. (2004). Exploring the "limits to growth" in UK organics: Beyond the statistical image. Journal of Rural Studies, 20(3):345-357.

44. Snow, D. A.; Soule, S. A. i Kriesi, H., ur. (2004). The Blackwell companion to social movement. Malden/Oxford/Carlton: Blackwell Publishing.

45. Šimleša, D. (2010). Ekološki otisak: kako je razvoj zgazio održivost. Zagreb: TIM press. Institut društvenih znanosti Ivo Pilar.

46. Tompkins, P. i Bird, C. (1998). Tajni život tla. Zagreb: Prosvjeta.

47. Tovey, H. (1997). Food, environmentalism and rural sociology: on the organic farming movement in Ireland. Sociolologia Ruralis, 37(1):21-37.

48. Tovey, H. (2002). Alternative Agriculture Movements and Rural Development Cosmologies. International Journal of Sociology of Agriculture and Food, 10(1).

49. Trainer, T. (2002). Debating the significance of the Global Eco-village Movement: A Reply to Takis Fotopoulos. Democracy \& Nature, 8(1):143-157.

50. Zeman, Z. i Geiger Zeman, M. (2011). "Živi zeleni san" - poetika konzumerističkog environmentalizma $i$ "odgovorni kapitalizam". Izlaganje na znanstvenom simpoziju Razvoj i okoliš - perspektive održivosti, Zagreb, 6.-7. listopada 2011. 
Preliminary note

Jelena Puđak

Institute of Social Sciences Ivo Pilar

jelena.pudjak@pilar.hr

Nataša Bokan

Faculty of Agriculture, University of Zagreb

nbokan@agr.hr

\title{
Organic Agriculture - Indicator of Social Values
}

\begin{abstract}
In the light of increasing environmental problems, it is necessary to recognize social moments which comprise and/or arise from those very same problems. One of those moments is food production which contributed to environmental and social problems mainly through conventional agriculture. Organic agriculture is an alternative approach to food production which implies specific social relations, and relations to the nature and technology. Although conventional food production is still predominant, organic agriculture is a fast spreading practice, as a way to a healthier life, as surviving strategies for rural and in some parts urban population, and as a worldview. In this paper we will try to provide answers about facts organic agriculture emerges from, about its forms, and about the implications it arises. We will also induce environmental, economic and socio-cultural benefits of organic agriculture that should be, given the proportion of environmental devastation, one of the most relevant issues. Ways in which organic agriculture is part of broader, alternative social movement and lifestyle will be considered as well. Finally, we will analyse the state and the possibilities of organic agricultural production in the world and in Croatia. Conclusion of the article is twofold. On one hand, due to paradigmatic adherence, adoption of alternative ideas is slow, and very often unacceptable; on the other hand, organic agriculture is an activity and a social value which expands worldwide, and therefore it is substantial to identify it both theoretically and socially.
\end{abstract}

Key words: organic agriculture, sustainability, agricultural production, conventional agriculture, alternative social movements. 